\title{
Soil carbon and nitrogen losses following deforestation in Ethiopia
}

\author{
Tesfay Berihu ${ }^{1} \cdot$ Gebreyohannes Girmay $^{1} \cdot$ Mulugeta Sebhatleab $^{1} \cdot$ Emiru Berhane $^{1}$. \\ Amanuel Zenebe ${ }^{1,2} \cdot$ Gilbert C. Sigua $^{3}$
}

Accepted: 30 November 2016 / Published online: 19 December 2016

(C) INRA and Springer-Verlag France 2016

\begin{abstract}
Ethiopia faces high risk of soil carbon depletion for nearly half of its total land mass largely due to forest clearing and continuous cultivation. Conversion of natural ecosystems to cultivated agriculture resulted in losses of between 20 and $50 \%$ of the soil C stocks in the first meter of the soil depth. Dry Afromontane forests of northern Ethiopia have faced vast exploitation, and almost all these forests have been converted to agricultural lands affecting the functionality and stability of agroecosystem. Here, we studied the effect of land use-land cover changes on soil organic $\mathrm{C}$, total $\mathrm{N}$, and soil $\mathrm{C}$ sequestration. Specifically, (a) we characterized major soils of the Desa'a Dry Afromontane forest, northern Ethiopia, and (b) we analyzed the organic $\mathrm{C}$ and total $\mathrm{N}$ contents of soils with varying land use-land cover types of the Desa'a Dry Afromontane forest. Results show that soil organic C (1.9\%) and total $\mathrm{N}(0.3 \%)$ were higher for the middle landscape position than that observed for the upper and lower landscape positions. Soil organic $\mathrm{C}$ that ranged from 1.2 in farmland to $2.3 \%$ in dense forest also varied with land use-land cover types. Concentration of soil organic $\mathrm{C}$ was different among dense forest (2.3\%), open forest (1.7\%), grazing land (1.6\%), and farmland $(1.2 \%)$. Due to the effect of land use-land cover types, soil total $\mathrm{N}$ varied from $0.2 \%$ in the farmland to $0.3 \%$ in the dense forest. The soil organic $\mathrm{C}$ and total nitrogen of the
\end{abstract}

Gilbert C. Sigua

gilbert.sigua@ars.usda.gov

1 Department of Land Resources Management and Environmental Protection, Mekelle University, Mekelle, Ethiopia

2 Institute of Climate and Society, Mekelle University, Mekelle, Ethiopia

3 US Department of Agriculture-Agriculture Research Service, Coastal Plains Soils, Water, and Plants Research Center, Florence, SC 29501, USA top and lower layer soils were 2.0 and 1.5 and 0.2 and $0.3 \%$, respectively. The soil organic $\mathrm{C}$ sequestration for dense forest was significantly higher $\left(48.5 \mathrm{t} \mathrm{ha}^{-1}\right)$ than that of grassland, open forest, and farm land. The top soil sequestered higher soil organic C $\left(44.9 \mathrm{t} \mathrm{ha}^{-1}\right)$ than the lower soil layer. Thus, the top soil layers of dense forest at the middle landscape positions stored significant amount of soil organic carbon.

Keywords Land use $\cdot$ Land cover $\cdot$ Soil properties $\cdot$ Soil organic carbon $\cdot$ Carbon sequestration $\cdot$ Ethiopia

\section{Introduction}

Ethiopia faces high risk of soil carbon depletion for nearly half of its total land mass largely due to forest clearing and continuous cultivation (Solomon et al. 2002; Mulugeta 2012). Soils store organic carbon (Woodfine 2009) globally estimated to a total of about 2500 gigaton which is twice of that in the atmosphere and four times in aboveground biomass (Batjes 1999; Eswaran et al. 1993; Lal 2004; Lehmann 2009). Conversion of natural ecosystems to cultivated agriculture and pasture land resulted in losses of between 20 and $50 \%$ of the soil carbon stocks in the first meter of the soil depth (FAO 2007). Conversion of natural ecosystems to cultivated agriculture resulted in losses of between 20 and $50 \%$ of the soil C stocks in the first meter of the soil depth. Dry Afromontane forests of northern Ethiopia have faced vast exploitation due to the intensification land-use changes has affected the functionality and stability of agroecosystem (shown in Fig. 1).

Soil carbon sequestration is the removal and storage of carbon dioxide from the atmosphere in soils through physical or biological processes, such as photosynthesis (IPCC 2001). Restoration of degraded land is the key to address sustainability in rapidly changing global scenarios 
Fig. 1 The Dry Afromontane forests of northern Ethiopia have faced vast exploitation, and almost all these forests have been converted to agricultural lands and pasturelands (transformation from picture a to picture $\mathbf{b}$ )
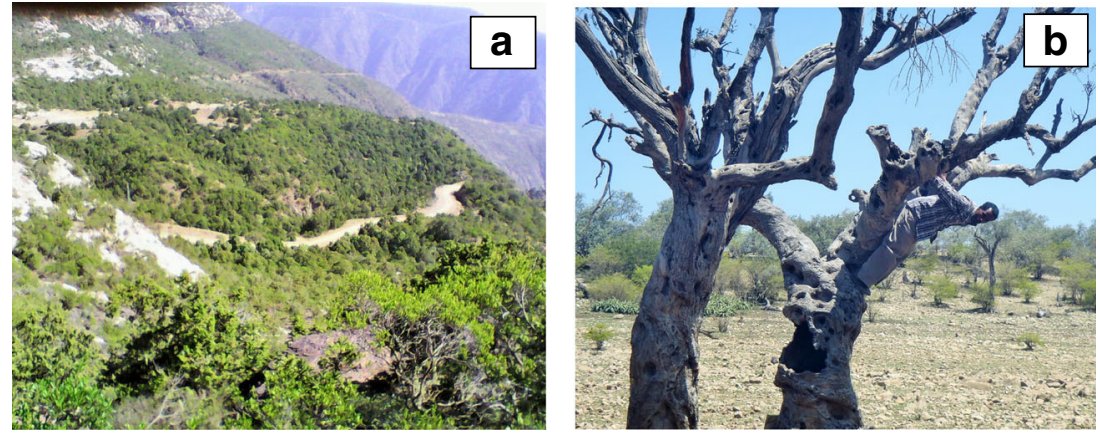

(Crossley et al. 1992). A common goal for the restoration of any natural ecosystem is to recover autogenic processes to the point where assistance from restorations is no longer needed. Therefore, the major challenge is to facilitate natural regeneration and create habitats where they can thrive and recreate the forest (Alemayehu 2007; Berhanu 2000). The need for assessing soil properties has been expanded for determining the consequences of management practices on soil quality relative to the sustainability of forest ecosystems (Schoenholtz et al. 2000). The physical and chemical characteristics of forest soils vary in space and time because of variations in topography, climate, weathering processes, vegetation cover, microbial activities, and several other biotic factors (Paudel and Sah 2003). Variations in soil nutrients across slope gradients are the results of combined factors of natural and human driven activities. Nutrient dynamics is the main driving force for determining physical and chemical properties of soils within a soil mapping unit at different locations and soil depth ranges (Bhandari and Ficklin 2009). Leaf litter in forests is an important factor in the transfer of energy and plant nutrients to forest soils. Climatic factors may strongly affect the nutrient status of litter since storms, and dry periods may give rise to early litter fall (Johnson 1995).

The soil carbon stock varies with land use and land management systems; hence, the uncertainty in soil carbon stock data is high. Despite the advances in soil survey around the world, data on soil bulk density is scarce relative to that on soil organic carbon content. Both variables are needed for the calculation of volume-based soil organic carbon stock and its possible change; consequently, a modeling approach is required to fill the gap between the available soil data in order to produce a soil carbon assessment. Carbon stock in the top $30 \mathrm{~cm}$ of soil in humid tropical forests ranges from 5 to $180 \mathrm{Mg} \mathrm{ha}^{-1}$ (IPCC 2006), and changes in soil carbon content are influenced by various factors such as soil tillage and organic matter inputs (Sigua et al. 2009; Sigua and Coleman 2010). About $30 \%$ of soil organic matter may be lost when forest is converted to agricultural plantations (Murty et al. 2002).

The Dry Afromontane forests of Ethiopia (Fig. 1) have faced vast exploitation and almost all these forests have been converted to agricultural lands (EFAP 1994; Demel 1997;
Tesfaye et al. 2003), except for small fragments that were left in the most inaccessible areas or around churches (Alemayehu et al. 2005; Aerts et al. 2006). The disappearance of the forests has been most drastic during the past 100 years. In the beginning of the 1900s, the forested area of the country was estimated at about $40 \%$ (EFAP 1994) but downscaled to $4.2 \%$ in 2001 (FAO 2001). The forest cover for Tigray region in northern Ethiopia has been reported to be less than $1 \%$ of the land area (TFAP, Tigrai Forestry Action Program 1996). These remnants are found in small patches dispersed over the region, of which Desa'a protected forests area is one. Desa'a protected area makes one of the 59 National Forests Priority Areas (NFPAs) in Ethiopia (BoPED 1995). This particular area deserved additional assessment because of the following reasons: (a) it has a better concentration of biodiversity; (b) it is the largest natural reserve compared to the other few small patches found dispersed in the region; and (c) it can better explain the evolution and type of threats that prevailed in forest of the region (Zenebe 1999). Hence, this study aims at understanding the effect of land use-land cover changes on soil organic carbon, total nitrogen, and soil carbon sequestration. Specific objectives were as follows: (a) to characterize major soils of the Desa'a Dry Afromontane forest, northern Ethiopia and (b) to analyze the organic carbon and total nitrogen contents of soils with varying land use-land cover types of the Desa'a Dry Afromontane forest.

\section{Materials and methods}

\subsection{Description of the study area}

Desa'a natural forest priority area is located at the eastern border of Eastern Tigray Zone, $\left(13^{\circ} 20^{\prime}-14^{\circ} 10^{\prime} \mathrm{N}\right.$; $39^{\circ} 32^{\prime}-$ $39^{\circ} 55^{\prime} \mathrm{E}$ ). It is composed of Dry Afromontane forest which is situated on the border between two regions of Ethiopia, namely, Tigray and Afar regions (Fig. 2). In the Tigray region, it touches two Woredas; Atsbi-Womberta in its northwest and Enderta in its southwest. The part of the protected area that lies in the Afar region touches the Kuneba and Abala Woredas. Desa'a forest is located about $80 \mathrm{~km}$ northeast of 


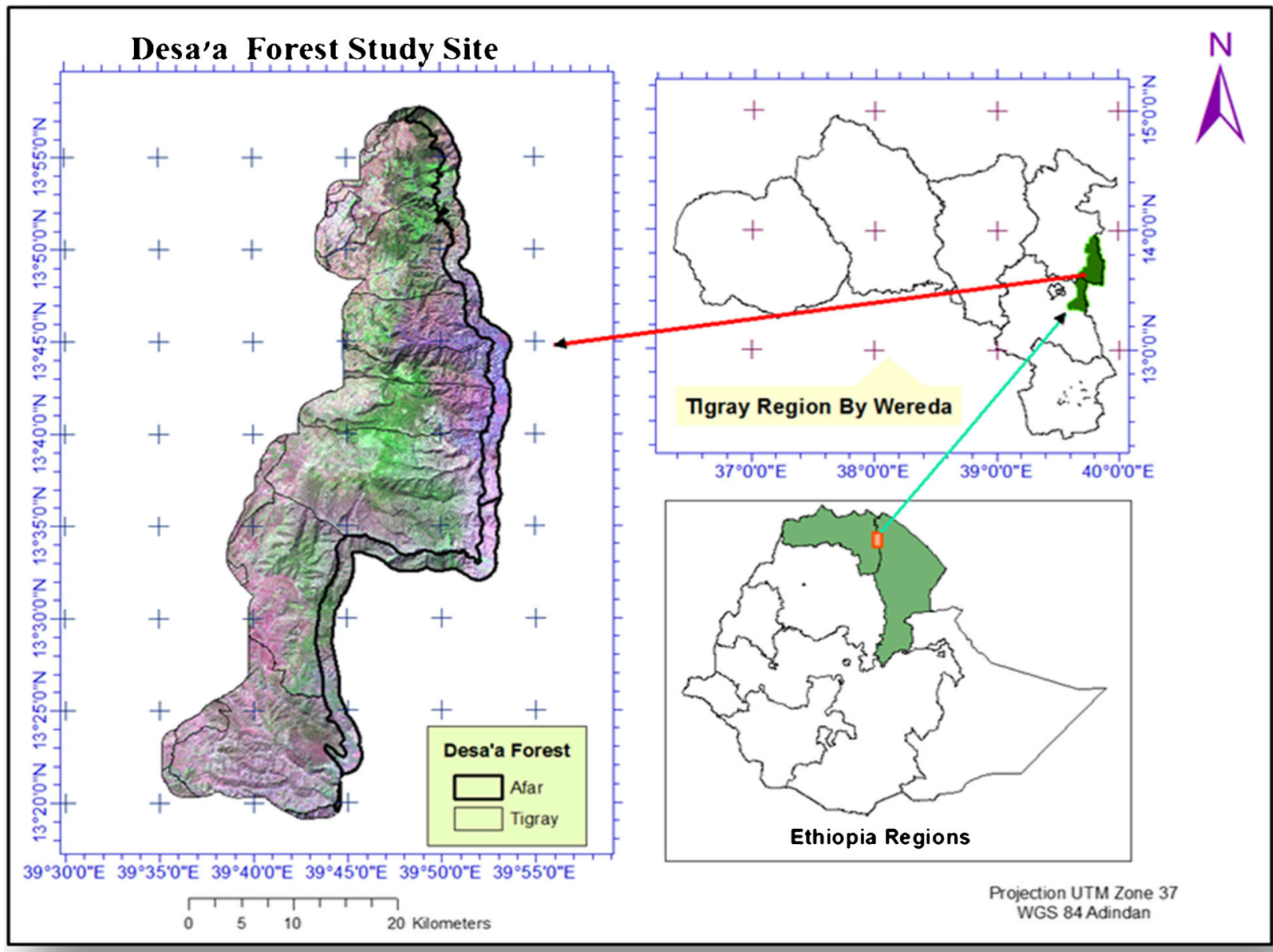

Fig. 2 Map showing the Desa's Forest study area

Mekelle city, the capital of the Tigray Regional State (BoANR IDC 1997). Most of Desa' $a$ forest is believed to lie within the Tigray region, although clear borders are not delineated yet on the ground. In 1993, the forest was declared as an NFPA and its current boundaries were delineated at that time (Zenebe 1999).

Topographically, the forest extends in an easterly direction downslope from the ridges of the western Escarpment of the Great East African Rift Valley towards the Dallol Basin and forms a climatic buffer zone between the cool highlands of Tigray and the hot lowlands in Afar region. The altitude of the area ranges from $900 \mathrm{~m}$ above mean sea level (AMSL) at the lower limit to about $3000 \mathrm{~m}$ AMSL at the plateau (Zenebe 1999). About $45 \%$ of the area has a slope class greater than 30\% (Ermias 2011). Geologically, a large part of Desa'a forest is formed on Enticho sandstone and crystalline Precambrian basement (Alemayehu et al. 2005; Asfawossen 2002). The dominant soil types are leptosols, cambisols, vertisols, regosols, and arenosols (BoANR IDC 1997). The study area is located in a semiarid agroecological zone where the climate is influenced by topography and exposure to rain-bearing winds (Nyssen et al.
2005). The data collected from meteorological stations located adjacent to the study area indicate that the plateau section of Desa'a forest receives a mean annual rainfall of $532 \mathrm{~mm}$ (Assefa 2005). Average temperature in the region is estimated to be $18{ }^{\circ} \mathrm{C}$ but varies greatly with altitude. The minimum and maximum temperatures of the area (Fig. 3) also vary in the range of 7.5 to 19.3 and 22.6 to $33.4{ }^{\circ} \mathrm{C}$, respectively (Zenebe 1999).

\subsection{Soil sampling and analysis}

During the field survey, various soil types were described. Three sites that represent the major soil types occurring in the Desa'a Dry Afromontane forest were identified. Morphological properties of the soils were described according to the FAO (1998) guidelines for soil description. A total of 21 soil samples were collected from each genetic horizon or layer of the soil pedons and analyzed for some soil physicochemical properties. Soil morphological properties were not included in this paper.

The study area was categorized into three landscape positions, upper; middle, and lower, and four major land use land 
a

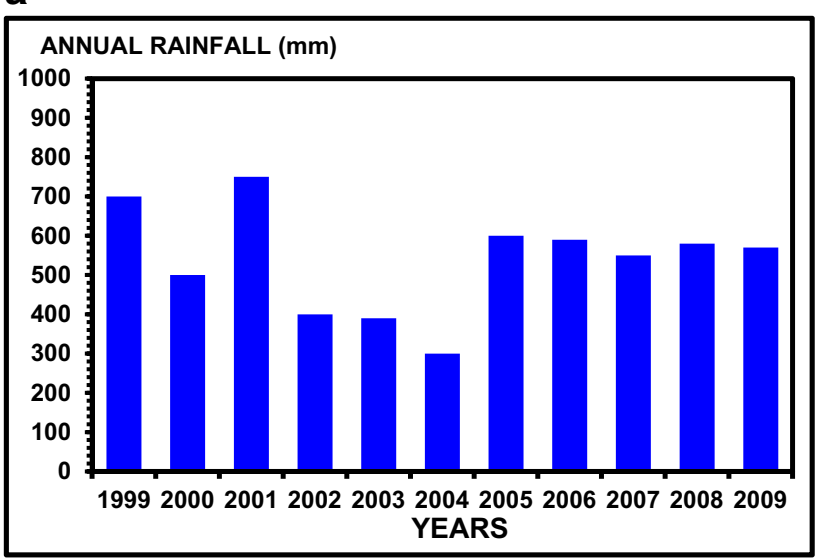

b

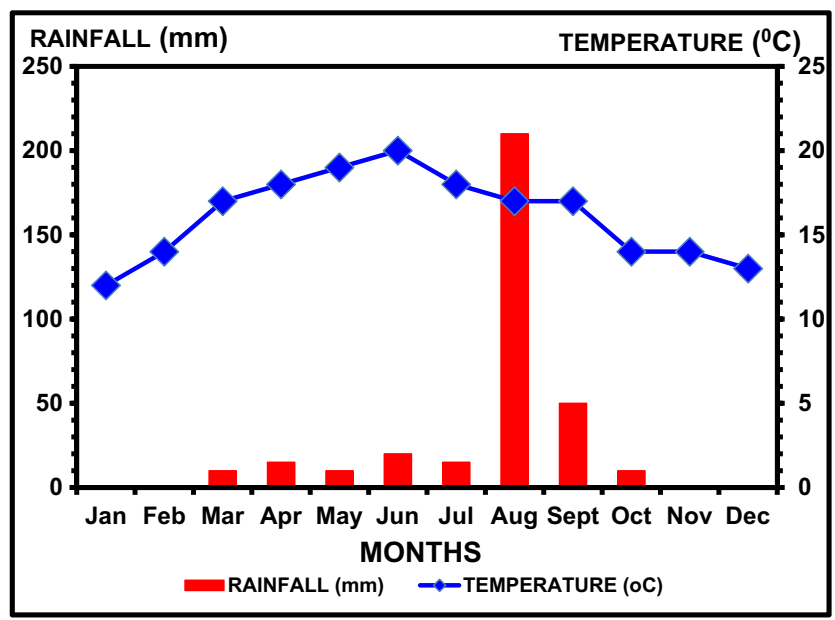

Fig. 3 a Annual rainfall (Assefa 2005) and $\mathbf{b}$ mean monthly rainfall and mean monthly temperature of Desa'a forest recorded at Atsbi meteorological station, northern Ethiopia

cover types, dense forest, open forest, farmland, and grazing land. Soil samples were randomly taken at the depth of 0-20 and $20-40 \mathrm{~cm}$ from each sampling site. A total of 72 soil samples were collected and transported to the laboratory, dried out in open air, and prepared to pass $2 \mathrm{~mm}$ mesh.

The soil organic carbon content was determined using the Walkley and Black (1934) wet combustion method using a mixture of orthophosphoric acid and barium diphenylamine sulfonate indicator and titrated with ferrous sulfate solution to a light green end point. The soil organic carbon content of each soil sample was then calculated and reported in percent. The total soil nitrogen in the soil samples was determined using the micro-Kjeldahl digestion and distillation (Bremner and Mulvaney 1982) method through destruction of organic matter by oxidation; the distillate was titrated using a $0.1 \mathrm{~N} \mathrm{HCl}$ to pink end point. Finally, total nitrogen content of each sample was calculated based on the readings obtained from the titration and reported as percent total nitrogen. The bulk density of the soil was determined from undisturbed soil samples using the core sampling technique.

The soil organic carbon accumulated in the soils was used in order to determine the amount of the sequestrated carbon $\left(\mathrm{g} / \mathrm{m}^{2}\right)$ according to Mahdavi et al. (2011) using the equation below.

$\mathrm{Cc}=1000 \times \mathrm{C} \times \mathrm{BD} \times \mathrm{e}$

where $\mathrm{Cc}$ is the amount of the sequestrated carbon; $\mathrm{C}$ is the accumulated amount of carbon (\%) per unit of sampling depth of soil; BD is the bulk density $\left(\mathrm{g} / \mathrm{cm}^{3}\right)$ of the soil; and e denotes the thickness of the soil depth in centimeters.

\subsection{Statistical analysis}

The different soil properties were statistically analyzed using the split-split plot design. The landscape positions (upper, middle, and lower) were considered as the main plot treatments, the land use-land cover types (dense forest, open forest, farmland, and grazing land) as sub-plot treatments, and the soil depths as sub-sub-plot treatments. During the statistical analysis, land use-land cover types (i.e., the sub-plot treatments) were compared to each of the landscape positions (i.e., to the main plot treatments) and to each of the soil sampling depths (i.e., to the sub-sub-plot treatments). Data were input and summarized using a Microsoft Excel software. Analyses of variances (ANOVAs) were computed. Soil properties with significant differences for each factor or combination of factors were separated using the least significant difference (LSD) test using the "MSTATC" software (Freed 1991).

\section{Results and Discussion}

\subsection{Soil organic C}

Soil organic carbon was significantly $(p<0.01)$ affected by landscape position. The observed soil organic carbon was significantly higher (1.9\%) for middle landscape position than that observed for the upper and lower landscape positions by 13.1 and $21.4 \%$, respectively (Table 1 ). There was no significant difference in soil organic carbon contents between the upper and lower landscape positions. The upper landscape position had higher soil organic carbon mean value than the lower landscape position.

Soil organic carbon also varied significantly $(p<0.05)$ with land use-land cover type that ranges from 1.2 to $2.3 \%$ in Desa'a forest (Table 1). The highest mean value was recorded on the dense forest, while the lowest was on farm land use type. Soil organic carbon of dense forest $(2.3 \%)$ was significantly $(p<0.05)$ greater than the open forest $(1.8 \%)$, grazing land $(1.6 \%)$, and farmland $(1.2 \%)$. The dense forest had higher value 
Table 1 Effects of landscape position, land use-cover type, and soil depth on selected soil physical and chemical properties at Desa'a Forest area

\begin{tabular}{|c|c|c|c|c|c|c|c|c|}
\hline \multirow[t]{2}{*}{ Treatments } & \multirow{2}{*}{$\begin{array}{l}\text { BD } \\
\left(\mathrm{g} / \mathrm{cm}^{3}\right)\end{array}$} & \multicolumn{7}{|c|}{ Particle size distribution } \\
\hline & & $\begin{array}{l}\text { Sand } \\
(\%)\end{array}$ & $\begin{array}{l}\text { Silt } \\
(\%)\end{array}$ & $\begin{array}{l}\text { Clay } \\
(\%)\end{array}$ & $\begin{array}{l}\mathrm{OC} \\
(\%)\end{array}$ & $\begin{array}{l}\mathrm{TN} \\
(\%)\end{array}$ & $\mathrm{C} / \mathrm{N}$ & $\begin{array}{l}\mathrm{CS} \\
\left(\mathrm{t} \mathrm{ha} \mathrm{a}^{-1}\right)\end{array}$ \\
\hline \multicolumn{9}{|l|}{ Landscape } \\
\hline ULS & $1.21 \mathrm{c}$ & $39.3 \mathrm{a}$ & $24.2 \mathrm{~b}$ & $36.5 \mathrm{a}$ & $1.69 \mathrm{~b}$ & $0.22 \mathrm{~b}$ & $8.17 \mathrm{a}$ & $38.94 b$ \\
\hline MLS & $1.22 \mathrm{~b}$ & $34.2 \mathrm{~b}$ & $30.5 \mathrm{a}$ & $35.3 b$ & $1.92 \mathrm{a}$ & $0.26 \mathrm{a}$ & $7.34 b$ & $43.41 \mathrm{a}$ \\
\hline LLS & $1.23 \mathrm{a}$ & $34.9 \mathrm{~b}$ & $30.5 \mathrm{a}$ & $34.6 b$ & $1.58 \mathrm{~b}$ & $0.23 \mathrm{ab}$ & $7.21 \mathrm{~b}$ & $37.41 \mathrm{c}$ \\
\hline $\operatorname{LSD}_{(0.05)}$ & 0.08 & 0.99 & 0.8 & 0.9 & 0.13 & 0.03 & 0.26 & 0.57 \\
\hline \multicolumn{9}{|l|}{ Land use } \\
\hline $\mathrm{OF}$ & $1.18 \mathrm{bc}$ & $36.19 b$ & $29.19 b$ & $34.62 \mathrm{c}$ & $1.77 \mathrm{~b}$ & $0.29 \mathrm{a}$ & $6.92 b$ & $38.60 \mathrm{c}$ \\
\hline DF & $1.11 \mathrm{c}$ & $33.12 d$ & $31.65 \mathrm{a}$ & $35.23 \mathrm{bc}$ & $2.30 \mathrm{a}$ & $0.31 \mathrm{a}$ & $7.29 b$ & $48.54 \mathrm{a}$ \\
\hline FL & $1.33 \mathrm{a}$ & $40.02 \mathrm{a}$ & $24.14 \mathrm{c}$ & $35.84 \mathrm{ab}$ & $1.24 \mathrm{c}$ & $0.15 b$ & $7.97 \mathrm{a}$ & $32.45 \mathrm{~d}$ \\
\hline GL & $1.26 \mathrm{ab}$ & $35.58 \mathrm{c}$ & $28.58 b$ & $35.84 \mathrm{a}$ & $1.62 \mathrm{~b}$ & $0.19 \mathrm{~b}$ & $8.10 \mathrm{a}$ & $40.09 \mathrm{~b}$ \\
\hline $\operatorname{LSD}_{(0.05)}$ & 0.13 & 1.02 & 0.88 & 1.02 & 0.28 & 0.09 & 0.44 & 1.31 \\
\hline \multicolumn{9}{|l|}{ Soil depth } \\
\hline Top & $1.19 b$ & $33.80 \mathrm{ab}$ & $30.67 \mathrm{a}$ & $35.53 \mathrm{a}$ & $1.97 \mathrm{a}$ & $0.26 \mathrm{a}$ & $7.71 \mathrm{a}$ & $44.89 \mathrm{a}$ \\
\hline Lower & $1.25 \mathrm{a}$ & $38.40 \mathrm{a}$ & $26.13 b$ & $35.46 \mathrm{a}$ & $1.50 \mathrm{~b}$ & $0.20 \mathrm{~b}$ & $7.44 b$ & $34.95 \mathrm{~b}$ \\
\hline
\end{tabular}

Means within the column, followed by the same letters, are not significantly different at $5 \%$ level

$B D$ bulk density, $U L S$ upper landscape, $M L S$ middle landscape, $L L S$ lower landscape, $O F$ open forest, $D F$ dense forest, $F L$ farm land, $G L$ grazing land, $C S$ carbon sequestered, Soil depth $(0-20 \mathrm{~cm})$, Lower soil depth $(20-40 \mathrm{~cm}), L S D_{(0.05)}$ least significant difference at $p<0.05$

in soil organic carbon than the open forest, grazing land, and farmland by about $0.5,0.7$, and $1.1 \%$, respectively (Table 1 ).

The soil organic carbon of the top and lower soil depths were 1.9 and $1.5 \%$ (Table 1). The soil organic carbon of top soil depth was higher than the lower soil depth by about $0.5 \%$. The total nitrogen of the two soil depths ranges from 0.2 to $0.3 \%$; mean value recorded on the top soil was higher by about $0.1 \%$ than that of the lower soil layers. As a result, the $\mathrm{C} / \mathrm{N}$ ratio of the top and the lower soil layers were 7.7 and 7.4 leading to a variation by a factor of $3.5 \%$. The estimate on carbon sequestration varied significantly $(p<0.05)$ between the top and lower soil depths. The top soil depth sequestered higher carbon $\left(44.9 \mathrm{t} \mathrm{ha}^{-1}\right)$ than the lower soil layer by about 9.9\% (Table 1).

The soil organic carbon contents as affected by the interactions among the land use types and soil depths range from 1.2 to $2.6 \%$ (Table 2). The highest mean value was recorded on top soils of the dense forest. The lowest soil organic carbon was recorded on the lower soil depths of farmland use type. The top soils of dense forest (DF-T) had significantly $(p \leq 0.05)$ higher carbon contents of $2.6 \%$ than other combinations (Table 2). Similarly, soil organic carbon contents ranges from $1.1 \%$ on farmlands of the middle landscape position to $2.7 \%$ in the dense forest of the middle landscape position (Table 2).

On many other studies, it has been found that conversion of forest land to cultivated land and grazing land results in loss of soil organic carbon. Similarly, results of our study showed the highest soil organic carbon for soils under dense forest followed by open forest land, grazing land, and farmland in both soil depths of $0-20$ and $20-40 \mathrm{~cm}$. The total nitrogen was also highest in soils under dense forest. Furthermore, we have observed a strong correlation between the soil organic carbon and the total nitrogen as well as different land use-land cover types. Research results from the Amazonian basin (e.g., Desjardins et al. 2004) indicate that conversion from forest to pasture induced an increase in soil organic carbon content. They suggested that pasture management plays an important role in soil organic carbon accumulation or loss. However, Yimer et al. $(2006,2007)$ reported that soils under forest and grazing land showed no significant difference with respect to soil organic carbon and total nitrogen contents.

The conversion of grassland to pasture, and vice versa, probably does not lead to large changes in soil organic carbon stocks, unless the land is overgrazed (Houghton and Goodale 2004). Whether pasture soils are a net sink or a net source of soil organic carbon will depend on their pasture management (Feamside and Barbosa 1998). Pastures with grazing intensity strongly influenced soil organic carbon declines and/or increases after land conversion. If pastures are overgrazed, inputs from aboveground parts are reduced, and soil carbon stocks could have decreased (Murty et al. 2002; Wei et al. 2010). As expected, the difference is most pronounced in the top soil (0$20 \mathrm{~cm})$ depth than in the lower soil depth $(20-40 \mathrm{~cm})$ for both soil organic matter and total nitrogen. The nearer to the soil 
Table 2 Interaction effect of land use-land cover type and depth, landscape position and land use/cover type, and landscape and depth on soil physical and chemical properties of Desa'a Forest area

\begin{tabular}{|c|c|c|c|c|c|c|c|c|}
\hline \multirow[t]{2}{*}{ Treatments } & \multirow[t]{2}{*}{$\mathrm{BD}\left(\mathrm{g} / \mathrm{cm}^{3}\right)$} & \multicolumn{7}{|c|}{ Particle size distribution (\%) } \\
\hline & & Sand & Silt & Clay & $\mathrm{OC}(\%)$ & $\mathrm{TN}(\%)$ & $\mathrm{C} / \mathrm{N}$ & $\mathrm{CS}\left(\mathrm{t} \mathrm{ha}^{-1}\right)$ \\
\hline \multicolumn{9}{|l|}{$\mathrm{LUC} \times \mathrm{D}$} \\
\hline OF-T & $1.15 \mathrm{~b}$ & $34.81 \mathrm{~cd}$ & $29.04 \mathrm{c}$ & $36.15 b c$ & $1.778 \mathrm{bc}$ & $0.33 \mathrm{a}$ & $6.64 \mathrm{~b}$ & $38.54 \mathrm{~cd}$ \\
\hline OF-L & $1.22 \mathrm{ab}$ & $37.57 \mathrm{~b}$ & $29.35 c$ & $33.08 \mathrm{~d}$ & $1.763 b c$ & $0.26 \mathrm{ab}$ & $7.21 \mathrm{~cd}$ & $38.66 \mathrm{~cd}$ \\
\hline DF-T & $1.10 \mathrm{~b}$ & $29.9 \mathrm{e}$ & $32.41 \mathrm{a}$ & $37.69 \mathrm{~b}$ & $2.652 \mathrm{a}$ & $0.33 \mathrm{a}$ & $7.64 \mathrm{bc}$ & $56.49 \mathrm{a}$ \\
\hline DF-L & $1.12 b$ & $36.34 \mathrm{bc}$ & $30.88 b$ & $32.78 \mathrm{~d}$ & $1.956 \mathrm{~b}$ & $0.28 \mathrm{ab}$ & $6.96 \mathrm{~cd}$ & $40.59 \mathrm{c}$ \\
\hline FL-T & $1.28 \mathrm{ab}$ & $36.03 \mathrm{bcd}$ & $28.74 \mathrm{c}$ & $35.23 \mathrm{c}$ & $1.434 \mathrm{~cd}$ & $0.18 \mathrm{ab}$ & $7.69 \mathrm{bc}$ & $36.53 \mathrm{~d}$ \\
\hline FL-L & $1.38 \mathrm{a}$ & $44.01 \mathrm{a}$ & $19.55 \mathrm{e}$ & $36.44 b c$ & $1.051 \mathrm{~d}$ & $0.12 b$ & $8.27 \mathrm{ab}$ & $28.38 \mathrm{f}$ \\
\hline GL-T & $1.22 \mathrm{ab}$ & $34.5 \mathrm{~d}$ & $32.41 \mathrm{a}$ & $33.09 \mathrm{~d}$ & $2.002 \mathrm{~b}$ & $0.22 \mathrm{ab}$ & $8.89 \mathrm{a}$ & $48.01 \mathrm{~b}$ \\
\hline GL-L & $1.29 \mathrm{ab}$ & $35.73 \mathrm{~cd}$ & $24.75 d$ & $39.52 \mathrm{a}$ & $1.232 \mathrm{~d}$ & $0.15 b$ & $7.33 \mathrm{~cd}$ & $32.17 \mathrm{e}$ \\
\hline $\operatorname{LSD}_{(0.05)}$ & 0.21 & 1.728 & 1.443 & 1.702 & 0.4757 & 0.1648 & 0.74 & 2.207 \\
\hline \multicolumn{9}{|l|}{$\mathrm{LS} \times \mathrm{LUC}$} \\
\hline ULS-OF & $1.23 \mathrm{ab}$ & $38.64 \mathrm{~b}$ & $23.84 \mathrm{c}$ & $37.52 \mathrm{c}$ & $1.58 \mathrm{cde}$ & $0.22 \mathrm{abc}$ & $8.66 \mathrm{~b}$ & $38.28 \mathrm{~cd}$ \\
\hline ULS-DF & $1.03 \mathrm{~b}$ & $31.74 \mathrm{ef}$ & $28.42 b$ & $39.84 b c$ & $2.52 \mathrm{ab}$ & $0.21 \mathrm{abc}$ & $7.02 \mathrm{~cd}$ & $49.37 \mathrm{~b}$ \\
\hline ULS-FL & $1.31 \mathrm{ab}$ & $53.35 \mathrm{a}$ & $21.55 \mathrm{~d}$ & $25.10 \mathrm{~g}$ & $1.35 \mathrm{de}$ & $0.33 \mathrm{a}$ & $9.66 \mathrm{a}$ & $33.53 \mathrm{e}$ \\
\hline ULS-GL & $1.28 \mathrm{ab}$ & $33.58 \mathrm{de}$ & $22.90 \mathrm{~cd}$ & $43.52 \mathrm{a}$ & $1.34 \mathrm{de}$ & $0.19 \mathrm{abc}$ & $7.35 \mathrm{c}$ & $34.59 \mathrm{e}$ \\
\hline MLS-OF & $1.14 \mathrm{ab}$ & $37.74 \mathrm{~b}$ & $29.34 b$ & $32.92 \mathrm{def}$ & $1.99 b c$ & $0.24 \mathrm{ab}$ & $5.88 \mathrm{e}$ & $38.95 \mathrm{c}$ \\
\hline MLS-DF & $1.08 \mathrm{ab}$ & $34.04 \mathrm{de}$ & $33.95 \mathrm{a}$ & $32.01 \mathrm{ef}$ & $2.73 a$ & $0.21 \mathrm{abc}$ & $7.84 b c$ & $57.02 \mathrm{a}$ \\
\hline MLS-FL & $1.35 \mathrm{a}$ & $29.90 \mathrm{f}$ & $28.44 b$ & 41.66ab & $1.05 \mathrm{e}$ & $0.03 \mathrm{c}$ & $7.09 \mathrm{~cd}$ & $28.28 \mathrm{f}$ \\
\hline MLS-GL & $1.31 \mathrm{ab}$ & $34.95 \mathrm{~cd}$ & $30.27 b$ & $34.78 \mathrm{~d}$ & $1.91 \mathrm{bcd}$ & $0.26 \mathrm{ab}$ & $8.58 \mathrm{~b}$ & $49.40 \mathrm{~b}$ \\
\hline LLS-OF & $1.17 \mathrm{ab}$ & $32.20 \mathrm{ef}$ & $34.40 \mathrm{a}$ & $33.40 \mathrm{de}$ & $1.73 \mathrm{~cd}$ & $0.33 \mathrm{a}$ & $6.24 \mathrm{de}$ & $38.59 \mathrm{c}$ \\
\hline LLS-DF & $1.22 \mathrm{ab}$ & $33.59 \mathrm{de}$ & $32.57 \mathrm{a}$ & $33.84 \mathrm{de}$ & $1.66 \mathrm{cde}$ & $0.28 \mathrm{ab}$ & $7.04 \mathrm{~cd}$ & $39.23 \mathrm{c}$ \\
\hline LLS-FL & $1.34 \mathrm{a}$ & $36.80 \mathrm{bc}$ & $22.45 \mathrm{~cd}$ & $40.75 b$ & $1.33 \mathrm{de}$ & $0.18 \mathrm{abc}$ & $7.18 \mathrm{~cd}$ & $35.54 \mathrm{de}$ \\
\hline LLS-GL & $1.18 \mathrm{ab}$ & $36.80 \mathrm{bc}$ & $32.57 \mathrm{a}$ & $30.63 f$ & $1.60 \mathrm{cde}$ & $0.12 b c$ & $8.39 b$ & $36.28 \mathrm{cde}$ \\
\hline $\operatorname{LSD}_{(0.05)}$ & 0.28 & 2.33 & 1.98 & 2.33 & 0.64 & 0.20 & 0.99 & 2.99 \\
\hline \multicolumn{9}{|l|}{$\mathrm{LS} \times \mathrm{D}$} \\
\hline ULS-T & $1.23 \mathrm{ab}$ & $38.64 \mathrm{ab}$ & $25.21 \mathrm{c}$ & $36.15 \mathrm{ab}$ & $1.94 \mathrm{ab}$ & $0.19 \mathrm{bcd}$ & $8.46 \mathrm{a}$ & $46.92 \mathrm{a}$ \\
\hline ULS-L & $1.19 \mathrm{ab}$ & $40.02 \mathrm{a}$ & $23.14 d$ & $36.84 a$ & $1.46 \mathrm{c}$ & $0.35 \mathrm{ab}$ & $7.88 \mathrm{ab}$ & $30.96 \mathrm{c}$ \\
\hline MLS-T & $1.13 b$ & $31.29 \mathrm{~d}$ & $33.01 \mathrm{a}$ & $35.70 \mathrm{abc}$ & $2.29 \mathrm{a}$ & $0.12 \mathrm{~d}$ & $7.21 \mathrm{c}$ & $48.15 \mathrm{a}$ \\
\hline MLS-L & $1.31 \mathrm{a}$ & $37.03 \mathrm{c}$ & $27.97 b$ & $35.00 \mathrm{bc}$ & $1.55 \mathrm{c}$ & $0.19 \mathrm{~cd}$ & $7.48 b c$ & $38.68 \mathrm{~b}$ \\
\hline LLS-T & $1.21 \mathrm{ab}$ & $31.51 \mathrm{~d}$ & $33.71 \mathrm{a}$ & $34.78 \mathrm{bc}$ & $1.67 b c$ & $0.36 \mathrm{a}$ & $7.47 \mathrm{bc}$ & $39.60 \mathrm{~b}$ \\
\hline LLS-L & $1.25 \mathrm{ab}$ & $38.19 b c$ & $27.29 b$ & $34.52 \mathrm{c}$ & $1.49 \mathrm{c}$ & $0.34 \mathrm{abc}$ & $6.96 \mathrm{c}$ & $35.20 \mathrm{bc}$ \\
\hline $\operatorname{LSD}_{(0.05)}$ & 0.16 & 1.40 & 1.16 & 1.38 & 0.38 & 0.17 & 0.59 & 1.78 \\
\hline
\end{tabular}

Means within the column, followed by the same letters, are not significantly different at $5 \%$ level

$B D$ bulk density, $L U C$ land use/cover, $D$ depth, $O F$ open forest, $D F$ dense forest, $F L$ farm land, $G L$ grazing land, $T$ top $(0-20 \mathrm{~cm}), L$ lower (20-40 cm); $L S$ landscape, $U L S$ upper landscape, $M$ middle, $L L S$ lower landscape, $C S$ carbon sequestered

surface, the greater influence of land use change will have on the carbon content. The topsoil contains the most labile soil organic carbon sources, i.e., those most readily decomposed by soil microbes. Therefore, if soil organic carbon inputs are reduced, microbes will continue to decompose the existing organic matter until the majority of the soil organic carbon will exist as stable and inert complexes (Walker and Desanker 2004).

The gross differences in carbon inputs among the different land uses in our study were within the range of the results reported from research conducted in the southern parts of Ethiopia and elsewhere in the world (Davidson and Ackerman 1993; Solomon et al. 2002; Lemenih and Itanna 2004; Walker and Desanker 2004). Solomon et al. (2000) reported similar results from their study conducted in the semiarid tropics of Tanzania. However, the amounts of soil organic carbon reported here for the sub-humid tropical highland ecosystems studied are higher than the amounts reported for low land humid tropical forest soils (Van Noordwjik et al. 1997). 
On the other hand, Yimer et al. $(2006,2007)$ reported $69 \%$ of soil organic carbon and $68 \%$ of total nitrogen in cropland (15 years with barley cultivated) in comparison to forest land soils from a study conducted in the Bale Mountains for the upper $100 \mathrm{~cm}$ soil depth. In Chemoga watershed of northwestern Ethiopia, Bewket and Stroosnijder (2003) found 87\% of soil organic carbon in a cultivated field at higher elevation (3200-3500 m AMSL) and only $11 \%$ of the soil organic carbon in a site with lower elevation (2500-2600 m AMSL). Differences in soil organic carbon from the sites can be attributed to the basic differences in soil type, vegetation, and other climatic and management factors. This also indicates that further research is needed to address the issue in a more comprehensive way by considering all possible site factor combination and relation to get reliable results at the country level, which, in turn, is needed to estimate increased carbon storage and to mitigate $\mathrm{CO}_{2}$ emissions in the country. Lemenih and Itanna (2004) concluded that national estimates of $\mathrm{CO}_{2}$ emissions on the basis of few data sets will be highly unrealistic, particularly given the wide topographic, vegetation, climatic, and edaphic variabilities in Ethiopia. They suggested increasing the efforts in acquiring reliable information on the types of forest available, annual area cleared for each type, and the amount of carbon losses associated with conversion of each forest type for reliable accounting of national scale $\mathrm{CO}_{2}$ emissions as related to land use change and forestry in Ethiopia.

The litter from certain tree species may also be rich in phenolic and lignin, factors that greatly slow decomposition and carbon losses (Brady and Weil 2002). The rate of humus oxidation in the undisturbed forest would be considerably lower than in the tilled field because the litter would not be incorporated into the soil and the absence of physical disturbance would result in slower soil respiration. It is logical to expect that conversion of forests to pasture would decrease soil organic carbon stocks, as the temperature of the soil increases markedly when exposed to the sun in the pasture, a factor known to shift the equilibrium between formation and oxidation of organic carbon to a lower plateau (Feamside and Barbosa 1998). In both soil depths, $\mathrm{C} / \mathrm{N}$ ratio of grazing land and farmland is significantly higher than dense and open forest land. It can be assumed that this is caused by high turnover rates of soil organic carbon as well as heavy extraction of $\mathrm{N}$ by most crops and continuous low input cultivation in the area.

Reductions in carbon inputs, due to biomass removal, plus increased losses by erosion and runoff with agricultural practices can further change the soil organic carbon dynamics (Craswell and Lefroy 2001). Carbon compounds can be physically protected from breakdown by aggregation and the physical integrity of the organic material and by organic and mineral coatings, such as humified and clay particles, respectively (Oades 1988). Disruption of these physical and chemical barriers during tillage can increase soil organic carbon breakdown. Understanding the controlling factors in the breakdown of organic residues is likely to become an important factor in developing more sustainable farming systems (Craswell and Lefroy 2001).

Soil erosion, which is a common phenomenon in Ethiopia, also contributed to loss of soil organic matter (Yimer et al. 2006, 2007; Tang et al. 2010). Erosion can cause translocation of a considerable amount of soil, and often, the carbon content of the moving material is at least twice that of the average top soil, as lighter fractions (including surface plant litter) are transported more readily than heavier ones. In addition to losses from biomass removal, nutrients can be lost from deforested sites by increased soil nutrient mobilization and leaching, especially when little vegetation is present at the site (Hajabbasi et al. 1997). The subsequent decline will have important consequences for crop production because organic matter supplies most of the nitrogen taken up by unfertilized crops (Lemenih et al. 2005). From environmental point of view, soil organic matter plays a critical role in the global carbon balance, which is thought to be the major factor affecting global warming or the greenhouse effect (Brady and Weil 2002). Our research results that deal with soil organic carbon differences among different land uses will allow more understanding and quantifying efforts to mitigate the $\mathrm{CO}_{2}$ emission at national level in the country by improving land use practices through restoration of soil fertility and reforestation.

\subsection{Soil Total nitrogen}

The concentration of total nitrogen of soils in the middle landscape $(0.26 \%)$ position was significantly $(p \leq 0.05)$ higher than the upper $(0.22 \%)$ and lower $(0.23 \%)$ landscape positions (Table 1). Total nitrogen was significantly different among the farmlands at the upper and middle landscape positions and grazing at the lower landscapes.

Similar to that of soil organic carbon, total nitrogen $(0.31 \%)$ was highest in the dense forest, while the lowest mean value was recorded in farmland. The total nitrogen for samples obtained from dense forest was higher than that obtained from grazing land and farmland by about 0.12 and $0.16 \%$, respectively. Total nitrogen values of samples gathered from dense and open forest showed non-significant $(p>0.05)$ difference.

Total nitrogen for the top soil depth $(0-20 \mathrm{~cm})$ was significantly $(p<0.001)$ higher than the lower soil depth $(20$ $40 \mathrm{~cm}$ ) depth of the dense forest (Table 1). Even though there is no statistically significant difference between the dense forest and the open forest land, higher total nitrogen was registered for dense forest than the open forest soil for both soil depths. For all land uses, the upper $(0-20 \mathrm{~cm})$ depth showed higher nitrogen content than the lower depths $(20-40 \mathrm{~cm})$. Soil total nitrogen ranges from $0.13 \%$ obtained from lower soil layers of the middle landscape to $0.37 \%$ on top soils of 
the lower landscape position. Our results could be related to soil erosion in our study site. Soil erosion, which is a common phenomenon in Ethiopia, also contributed to loss of soil organic matter (Yimer et al. 2006, 2007). Erosion can cause translocation of a considerable amount of soil, and often, both the carbon and nitrogen contents of the moving material are at least twice that of the average top soil, as lighter fractions (including surface plant litter) are transported more readily than heavier ones. In addition to losses from biomass removal, nutrients can be lost from deforested sites by increased soil nutrient mobilization and leaching, especially when little vegetation is present at the site (Hajabbasi et al. 1997). The subsequent decline will have important consequences for crop production because organic matter supplies most of the nitrogen taken up by unfertilized crops (Lemenih et al. 2005). From environmental point of view, soil organic matter plays a critical role in the global carbon balance, which is thought to be the major factor affecting global warming or the greenhouse effect (Brady and Weil 2002).

Despite of some differences in the soil organic carbon content and total nitrogen, all findings indicated that soils under dense forest land have higher soil organic carbon and total nitrogen than soils under grazing land and farmland. Solomon et al. (2002) attributed the depletion of organic matter in the farmland soils to the drastic reduction of organic matter input and tillage practices, which frequently exposes aggregates to physical disruption by rapid wetting and rain drop impact as well as through shearing by agricultural implements. The net effect on the loss of soil organic matter could be explained by the stimulation of oxidation and exposure of the originally inaccessible organic matter to the attack of soil microorganisms. During cultivation, most mineralized organic nitrogen is lost and phosphorus reverts to unavailable forms, associated with calcium, iron, or aluminum in tropical soils (Tiessen et al. 1994). Incorporation of residues during tillage operations reduces the size of residue particles and increases the contact with soil particles and biota, thus producing increased breakdown of recently added organic carbon. Similar results were reported by Sigua et al. (2014). They reported that a number of factors could have affected the carbon mineralization of biochars. The rapidity and stability with which given biochars are oxidized in the soil will depend on biochars' physical and chemical compositions and the physical and chemical conditions of the surrounding soil environment. In addition, the $\mathrm{C} / \mathrm{N}$ ratio of the biochars, the age of the feedstocks, and the degree of disintegration or particle size of the biochars govern the rate of their decomposition.

\subsection{C/N ratio}

The $\mathrm{C} / \mathrm{N}$ ratio was significantly $(p<0.05)$ affected by land use-land cover type with average values ranging from 6.9 to 8.1 in Desa'a forest (Table 2). The $\mathrm{C} / \mathrm{N}$ ratio in grazing land was recorded as the highest while the lowest mean value was in the open forest. The $\mathrm{C} / \mathrm{N}$ ratio was significantly $(p<0.05)$ affected by land use-land cover. The observed $\mathrm{C} / \mathrm{N}$ value was higher for grazing land than for dense forest and open forest by 0.81 and 1.18 , respectively. The $\mathrm{C} / \mathrm{N}$ ratio showed higher values for grazing from both land use types and for dense forest from both land cover types.

The $\mathrm{C} / \mathrm{N}$ ratio of the interaction between landscape positions and land use types ranges from 5.9 on open forest at the middle landscape to 9.7 on the farmlands at the upper landscape (Table 2). The $\mathrm{C} / \mathrm{N}$ ratio ranges from 6.9 to 8.5 (Table 2). The highest was recorded on top soils of the upper landscape and lowest on lower soil layers of lower landscape position. The significant effect of the interactions of landscape positions and soil depths on $\mathrm{C} / \mathrm{N}$ ratio is shown in this order: ULS-T $>$ MLSL $>$ LLS-T $>$ MLS-T $=$ LLS-L. There was no significant difference in $\mathrm{C} / \mathrm{N}$ ratio between middle and lower landscape positions. Even though there is no significant difference between middle and lower landscape positions, a much higher mean value was recorded in the middle landscape position. The $\mathrm{C} / \mathrm{N}$ ratio showed significant difference for $0-20 \mathrm{~cm}$ depth $(p<0.001)$, among grazing land and other land uses in both depths. However, there was no significant difference between grazing land at the top soil depth and farm land at lower soil depth. The differences in the soil $\mathrm{C} / \mathrm{N}$ can be attributed to topographic aspect-induced microclimatic differences, which are causing differences in the biotic soil component. Differences in microclimate are often linked to varying soil moisture and erosion potential and, in turn, could be used to explain distribution of plant communities. Plants on southfacing slope are also more exposed to direct sunlight and are, therefore, subjected to intense sun, which results in higher surface temperatures and a drier environment while north-facing slope can benefit forage production because of lower surface temperature and wetter environment. Bonan (1989) also reported that north-facing slopes and level sites receive less solar radiation than south-facing slopes and, therefore, tend to be cooler and wetter. Most of the sunlight on northern aspects may be considered as reflected light from the atmosphere called diffuse sunlight. It has been suggested that nitrogen dynamics is the key parameter in regulating terrestrial carbon in the long term. Increased nitrogen deposition could increase atmospheric $\mathrm{CO}_{2}$ by stimulating biomass accumulation, hence affecting the long-term soil C/N (Giardina et al. 2003).

\subsection{Carbon sequestration}

The land use-land cover changes of the Desa'a Dry Afromontane forest was studied since 1970 by several researchers. The area coverage of each land use-cover type in 2010 was used to estimate the carbon sequestered at the top and lower depths of the forest soil for this study. The result showed that the highest amount of carbon sequestered at the 
top soil $\left(109 \mathrm{tha}^{-1}\right)$ and sub-soil $\left(114.7 \mathrm{t} \mathrm{ha}^{-1}\right)$ on the dense forest followed by the grassland with sequestered carbon about $105.7 \mathrm{tha}^{-1}$ on the top soil and $83.4 \mathrm{t} \mathrm{ha}^{-1}$ in the subsoil. The open forest had 83.7 and $63 \mathrm{tha}^{-1}$ of carbon sequestered by the topsoil and sub-soil, respectively. The farmland had the lowest amount of carbon sequestration $\left(26.1 \mathrm{t} \mathrm{ha}^{-1}\right.$ in topsoil and $17 \mathrm{t} \mathrm{ha}^{-1}$ by sub-soil). Our results were consistent with the findings of Zhang et al. (2013) and Prietzel and Bachman (2012). They reported that soils with different vegetations have different litter decomposition processes leading to the difference in release of carbon and nitrogen to soil. Tree species with different plant characteristics and stands can impact retention and sequestration of soil organic carbon and nitrogen. This may be partly explained by the increased of aboveground biomass and litter that add more organic matter to the soil. Similar study reported that converting soils under agriculture into perennial land use may increase soil organic carbon (Lal 2004).

Land use-land cover changes directly affect the carbon sequestration rate in soils of Desa'a forest. Carbon sequestration was significantly affected by the changes of land cover type and different soil depths. The dense forest had significantly higher carbon sequestration compared with grazing land, open forest land, and farmland due to minimal disturbance in the dense forest compared to other land use cover types. Overall, there was more soil carbon sequestered in the dense forest compared with other land use types. Reports from around the world indicate that the soil organic carbon declined by 20 to $43 \%$ after natural forest or perennial grassland is converted to agricultural land (Deng et al. 2016; Don et al. 2011). Afforestation and revegetation have been proposed as effective methods for reducing atmospheric $\mathrm{CO}_{2}$ due to carbon sequestration in vegetation and soils (IPCC 2007).

Carbon sequestration values showed significant difference among the three different landscape positions: MLS > ULS > LLS (Table 2). The carbon sequestration of middle landscape position $\left(43.4 \mathrm{t} \mathrm{ha}^{-1}\right)$ showed higher mean values than those values obtained for the upper $\left(38.9 \mathrm{t} \mathrm{ha}^{-1}\right)$ and lower $\left(37.4 \mathrm{t} \mathrm{ha}^{-1}\right)$ landscape positions. Likewise, estimated carbon sequestration was significantly $(p<0.05)$ affected by land usecover type (Table 2 ). The overall order of carbon sequestration among the different land use-land cover is as follows: DF > GL $>$ OF $>$ FL in Desa'a forest.

Soil carbon sequestration values of the interactions of the landscape positions and land use/cover types ranges from $28.28 \mathrm{t} \mathrm{ha}^{-1}$ on farmland at the middle landscape to $57.0 \mathrm{tha}^{-1}$ on the dense forest at the middle landscape position (Table 2). The carbon sequestration values of the interaction of middle landscape with dense forest were found to be significantly higher $\left(57.0 \mathrm{t} \mathrm{ha}^{-1}\right)$ than all interactions of the landscape positions with land use types (Table 2). The differences in the soil carbon sequestration may be attributed to topographic aspect-induced microclimatic differences, which are causing differences in the biotic soil component. Differences in microclimate are often linked to varying soil moisture and erosion potential and, in turn, could be used to explain distribution of plant communities. Plants on south-facing slope are also more exposed to direct sunlight and are, therefore, subjected to intense sun, which results in higher surface temperatures and a drier environment, while north-facing slope can benefit forage production because of lower surface temperature and wetter environment. Bonan (1989) also reported that north-facing slopes and level sites receive less solar radiation than south-facing slopes and, therefore, tend to be cooler and wetter. Most of the sunlight on northern aspects may be considered reflected light from the atmosphere called diffuse sunlight. Our results are consistent with the results of Coble et al. (2001) who reported that in typical forest environment, south-facing slope is less productive than north-facing slope.

\section{Conclusion}

The soil carbon sequestration of middle landscape position $\left(43.4 \mathrm{t} \mathrm{ha}^{-1}\right)$ showed higher mean values than those obtained for the upper $\left(38.9 \mathrm{t} \mathrm{ha}^{-1}\right)$ and lower $\left(37.4 \mathrm{tha}^{-1}\right)$ landscape positions. The carbon sequestration for dense forest was significantly higher $\left(48.5 \mathrm{tha}^{-1}\right)$ than grassland, open forest, and farm land. The estimate on carbon sequestration varied significantly $(p<0.05)$ between the top and lower soil depths. The top soil depth sequestered higher carbon $\left(44.9 \mathrm{tha}^{-1}\right)$ than the lower soil layer.

Our results support the hypothesis that conversion of forest to other land use may lead to massive losses in soil carbon, soil nitrogen, and other nutrients. Thus, the present land management is not sustainable. For low external input farming system in the study area, the changes in soil organic carbon and other parameters will have implications in productivity of the system as well as environmental degradation. The influence of land use change is more pronounced in the $0-20 \mathrm{~cm}$ depth than $20-40 \mathrm{~cm}$ depth indicating the effect of management more on the upper soil depth. The global effort towards finding sustainable solutions to the greenhouse effect has identified the potential of soils as a carbon sink. However, for an accurate and reliable large-scale determination of soil organic carbon stock, density depends on soil organic carbon density determination at local or small-scale level (Su et al. 2006).

Furthermore, our present research demonstrated that the land use-land cover changes could directly affect the soil physical and chemical properties, especially soil organic carbon status. Below are few recommendations based on the outcome of our study:

- There is a need for change in policies and strategies for sustainable land use that will integrate development with 
sustainable management of the environment. Improved management of soils is very essential to sustain soil quality and improve the productivity of farmlands which, in turn, can help to reduce deforestation and soil degradation;

- Awareness creation especially for farmers who live nearby the Desa'a forest on the benefits of having a protected forest area and use of their land in a sustainable way;

- Different stake holders like governmental and NG organizations and researchers have to create knowledge to generally orient the society regarding the enhancement of global warming in relation to unwise use of land and forest resources;

- Implementation of socioeconomic incentives like that of fertilizer subsidy and other packages to induce land users to promote or adopt sustainable land management practices; and

- Adoption of public based on knowledge and evidences obtained through research on the role of soil organic carbon in mitigating climate change as well as the potential for financial benefits from the carbon trading systems.

A common goal for the restoration of any natural ecosystem is to recover autogenic processes. Therefore, the major challenge is to facilitate natural regeneration and create habitats where they can thrive and recreate the forest. In our study, we demonstrated the need for assessing soil properties that has been expanded for determining the consequences of management practices on soil quality relative to the sustainability of forest ecosystems. The soil carbon stock varies with land use and land management systems; hence, the uncertainty in soil carbon stock data is high. Despite the advances in soil survey around the world, data on soil bulk density is scarce relative to that on soil organic carbon content. Both variables are needed for the calculation of volume-based soil organic carbon stock and its possible change; consequently, a modeling approach is required to fill the gap between the available soil data in order to produce a soil carbon assessment. Our results provided valuable information for the data and research gap applicable to other countries having similar problems of continued land use and land cover changes due changing climate.

\section{References}

Aerts R, Maes W, November E, Negussie A, Hermy M, Muys B (2006) Restoring dry Afromontane forest using bird and nurse plant effects: direct sowing of Olea europaea sub species p. cuspidatae seeds. For Ecol Manag 230:23-31. doi:10.1016/j.foreco.2006.04.001

Alemayehu WE (2007) Ethiopian Church Forests: opportunities and challenges for restoration. $\mathrm{PhD}$ thesis, Wageningen Univeristy, Wageningen, The Netherlands. ISBN: 978-90-8504-768-1
Alemayehu W, Demel T, Powell N (2005) Church forests in North Gondar Administrative Zone, northern Ethiopia. Forests, Trees and Livelihoods 15:349-374. doi:10.1080/ 14728028.2005.9752536

Asfawossen A (2002) The rock-hewn churches of Tigari, northern Ethiopia: a geological perspective. Geoarcheology 17(7):649-663. doi:10.1002/gea.10035

Assefa A (2005) Farm management in mixed crop-livestock systems in the Northern Highlands of Ethiopia. Ph.D. Dissertation, Wageningen University and Research Center. ISBN: 90-8504$303-4$

Batjes NH (1999) Management options for reducing $\mathrm{co}_{2}$-concentrations in the atmosphere by increasing carbon sequestration in the soil. Report 410-200-031, ISRIC Technical Paper 30, Dutch National Research Programme on Global Air Pollution and Climate Change \& Technical Paper 30, International Soil Reference and Information Centre, Wageningen

Berhanu G (2000) Policies for sustainable land management in the highlands of Tigray, project objectives, activities, organization and database: summary of papers and proceedings of a workshop, Mekelle, Ethiopia. 2002

Bewket W, Stroosnijder L (2003) Effects of agro ecological land use succession on soil properties in Chemoga watershed, Blue Nile basin, Ethiopia. Geoderma 111:85-98. doi:10.1016/S0016-7061(02)00255-0

Bhandari B, Ficklin RL (2009) Characterizing the variability of physical and chemical properties across the soil individuals mapped as amy silt loam soils in Southeastern Arkansas. Journal of the Arkansas Academy of Science, Vol. 63. https://libraries.uark. edu/aas/issues/2009v63/v63a6.pdf

BoANR IDC (1997) Desa'a state forest management plan, National Regional State of Tigray. Mekelle, Ethiopia

Bonan G (1989) A computer model of the solar radiation, soil moisture, and soil thermal regimes in boreal forests. Ecological Modeling 45: 275-306. doi:10.1016/0304-3800(89)90076-8

Brady NC, Weil RR (2002) The nature and properties of soils, 13th edn. Prentice Hall, Upper Saddle River, NJ 960 pp., ISBN 0-13-016763-0

Bremner JM, Mulvaney CS (1982) Nitrogen-total. In: Page AL, Miller RH (eds) Methods of soil analysis. Part 2, 2nd edn. Agron. Monogr. 9. ASA and SSSA, Madison, WI, pp. 595-624

Bureau of Planning and Economic Development (BoPED (1995) Five years development plan of the Tigray region. Bureau of Planning and Economic Development, Mekelle

Craswell ET, Lefroy RDB (2001) The role and function of organic matter in tropical soils. Nutrient Cycling and Agroecosystem 61:7-18. doi:10.1023/A:1013656024633

Coble DW, Milner KS, Marshal JD (2001) Above- and below-ground production of trees and other vegetation on contrasting aspects in western Montana. For Ecol Manag 142:231-241. doi:10.1016 /S0378-1127(00)00353-4

Crossley DA Jr, Mueller BR, Perdue JC (1992) Biodiversity of microarthropods in agricultural soils: relations to processes. Agricult Ecosyst Environ 40:37-46. doi:10.1016/0167-8809(92)90082-M

Davidson EA, Ackerman IL (1993) Changes in soil carbon inventories following cultivation of previously untilled soils. Biogeochemistry 20:161-193. doi:10.1007/BF00000786

Demel T (1997) The impact of clearing and converting dry Afromontane forests into permanent arable land on the composition and density of soil seed banks. Acta Oecolog 18:557-573. doi:10.1016/S1146-609 X(97)80041-0

Deng L, Wang G, Liu G, Shanguan Z (2016) Effects of age and land-use change on soil carbon and nitrogen sequestrations following cropland abandonment on the Loess Plateau. China Ecol Eng 90:105112. doi:10.1016/j.ecoleng.2016.01.086

Desjardins T, Andreux F, Volkoff B, Cerri CC (2004) Organic carbon and ${ }^{13} \mathrm{C}$ contents in soils and soil size-fractions, and their change due to deforestation and pasture installation in eastern Amazonia. Geoderma 61:103-118. doi:10.1016/0016-7061(94)90013-2 
Don A, Schumacher J, Freibauer A (2011) Impact of tropical land-use change on soil organic carbon stocks - a meta analysis. Glob Chang Biol 17:1658-1670. doi:10.1111/j.1365-2486.2010.02336.x

EFAP (1994) Ethiopian forestry action Program final report. http://ibcat. aau.edu.et/cgi-bin/koha/opac-detail.pl?bib=197653

Ermias A (2011) Forest diversity in fragmented landscapes of Northern Ethiopia and implications for conservation. Ph.D. Dissertation, Bonn. doi: 10.1.1.407.2442

Eswaran H, Bliss N, Lytic D, Lammers D (1993) Major soil regions of the world. USDA-SCS, Washington, DC

FAO (2001) Global Forest Resource Assessment. 2000. FAO Forestry paper 140. FAO. Rome

FAO (1998) Land cover classification system (LCCS): classification concepts and user manual. FAO, Rome

FAO (2007) Agriculture and water scarcity: a programmatic approach to water use efficiency and agricultural productivity. Twentieth Session, Committee on Agriculture, COAG/2007/7, Rome

Feamside PM, Barbosa IR (1998) Soil carbon changes from conversion of forest to pasture in Brazilian Amazonia. For Ecol Manag 108: 147-166. doi:10.1016/\%20S0378-1127(98)00222-9

Freed R, Eisensmith SP, Goetz S, Reicosky D, Smail VW, Wolberg P (1991) User's guide to MSTAT-C. Michigan State Univesity, East Lansing p 300

Giardina CP, Ryan MG, Binkley D, Fownes JH (2003) Primary production and carbon allocation in relation to nutrient supply in a tropical experimental forest. Glob Chang Biol 9:1438-1450. doi:10.1046 j.1365-2486.2003.00558.x

Hajabbasi MA, Jalalian A, Karimzadeh HR (1997) Deforestation effects on soil physical and chemical properties, Lordegan, Iran. Plant Soil 190:301-308. doi:10.1023/A:1004243702208

Houghton RA, Goodale CL (2004) Effects of land-use change on the carbon balance of terrestrial ecosystem. In: Defries RS, Asner P, Houghton RA (eds) Ecosystems and land-use change. American Geophysical Union, Washington, DC. doi:10.1029/153GM08

IPCC (2001) Climate change: the scientific basis. Cambridge University Press, Cambridge

IPCC (2006) IPCC guidelines for national greenhouse gas inventories. Prepared by The National Greenhouse Gas Inventories Programme. In: Eggleston HS, Buendia L, Miwa K, Ngara T, Tanabe K (eds.). Published by IGES, Japan

IPCC (2007) Climate change 2007: the physical science basis. In: Solomon S, Qin D, Manning M (eds) Contribution of Working Group 1 to the Fourth Assessment Report of the Intergovernmental Panel on Climate Change. Cambridge University Press, New York

Johnson DW (1995) Role of carbon in the cycling of other nutrients in forested ecosystems. Soil Science Society of America, Madison, WI, pp. 299-328

Lal R (2004) Soil carbon sequestration to mitigate climate change. Geoderma 123:1-22. doi:10.1016/j.geoderma.2004.01.032

Lehmann J (2009) Terra preta Nova - where to from here? In: Woods WI, Teixeira WG, Lehmann J, Steiner C, Winkler Prins A (eds) Terra preta Nova: a tribute to Wim Sombroek. Springer, Berlin, pp. 473486

Lemenih M, Itanna F (2004) Soil carbon stocks and turnovers in various vegetation types and arable lands along an elevation gradient in southern Ethiopia. Geoderma 123:177-188. doi:10.1016/j. geoderma.2004.02.004

Lemenih M, Erik K, Mats O (2005) Assessing soil chemical and physical property responses to deforestation and subsequent cultivation in small holders farming system in Ethiopia. Agriculture, Ecosystem and Environment 105:373-386. doi:10.1016/j.agee. 2004.01.046

Mahdavi M, Arzani H, Mesdaghi KH, Mahdavi KH, Mahmodi J, Alizadeh M (2011) Estimation of soil carbon sequestration rate in steppes (case study: Saveh Rudshur steppes). Journal of Rangeland
Science 1(3):175-182 http://www.rangeland.ir/article_513047_ \%20cd34a3db73b0edcc2212faa76957d76d.pdf

Mulugeta S (2012) Unpublished MSc thesis titled as 'Forest cover change detection and susceptibility mapping using GIS and remote sensing in Desa'a forest, North Ethiopia'

Murty D, Kirschbaum MF, Mcmurtrie R, Mcgilvray H (2002) Does conversion of forest to agricultural land change soil carbon and N? A review of the literature. Glob Chang Biol 8:105-123. doi:10.1046 j.1354-1013.2001.00459.x

Nyssen J, Vandenreyken H, Poesen, J (2005) Rainfall erosivity and variability in the northern Ethiopian highlands. J Hydrol 311:172-187. doi:10.1016/j.jhydrol.2004.12.016

Oades J (1988) The retention of organic matter in soils. Biogeochemistry 5:35-70. doi:10.1007/BF02180317

Paudel S, Sah JP (2003) Physiochemical characteristics of soil in tropical forests in eastern Nepal. Himal J Sci 1:107-110. doi:10.3126/njst. v14i1.8876

Prietzel EB, Bachman S (2012) Changes in soil organic C and N stocks after forest transformation from Norway spruce and Scots pine into Douglas fir, Douglas fir/spruce, or European beech stands at different sites in southern Germany. Forest Ecol Manag 269:134-148. doi:10.1016/j.foreco.2011.12.034

Schoenholtz S, Miegroet H, Van H, Burger JA (2000) A review of chemical and physical properties as indicators of forest soil quality: challenges and opportunities. For Ecol Manag 138:335-356. doi:10.1016/S0378-1127(00)00423-0

Sigua GC, Novak J, Watts D, Cantrell K, Shumaker P, Szogi A, Johnson M (2014) Carbon mineralization in two ultisols amended with different sources and particle sizes of biochar. Chemosphere 103:313321. doi:10.1016/j.chemosphere.2013.12.024

Sigua GC, Coleman SW (2010) Spatial distribution of soil carbon in pastures with cow-calf operation: effects of slope aspect and slope position. J Soils Sediments 10:240-247. doi:10.1007/s11368-0090110-0

Sigua GC, Coleman SW, Albano J (2009) Beef cattle pasture to wetland reconversion: impact on soil organic carbon and phosphorus dynamics. Ecol Eng 35:1231-1236. doi:10.1016/ j.ecoleng.2009.05.00 4

Solomon D, Fritzsche F, Tekalign M, Lehmann J, Zech W (2002) Soil organic matter composition in the sub-humid Ethiopian highlands as influenced by deforestation and agricultural management. Soil Sci Soc Am J 66:68-82. doi:10.2136/sssaj2002.6800

Solomon D, Lehmann J, Zech W (2000) Land use effects on soil organic matter properties of chromic luvisols in semiarid tropics: carbon, nitrogen, lignin and carbohydrates. AgricEco Environ 78:203-213. doi:10.1016/S0167-8809(99)00126-7

Su ZY, Xiong YM, Zhu JY, Ye YC, Ye M (2006) Soil organic carbon content and distribution in a small landscape of Dongguan, South China. Pedosphere 16(1):10-17. doi:10.1016/S1002-0160(06)60020-9

Tang X, Liu S, Liu J, Zhou G (2010) Effects of vegetation restoration and slope position on soil aggregation and soil carbon accumulation on heavily eroded tropical land of southern China. J Soils Sediments 10:505-513. doi:10.1007/s11368-009-0122-9

Tesfaye W, Ingrid K, Demel T, Franz O (2003) Mycorrhizal status of indigenous trees in dry Afromontane forests of Ethiopia. For Ecol Manag 179:387-399. doi:10.1016/S0378-1127(02)00546-7

TFAP (Tigrai Forestry Action Program) (1996) Main report, Regional Government of Tigray Bureau of Agriculture and Natural Resources. Mekelle, Ethiopia

Tiessen H, Cuevas E, Chacon P (1994) The role of soil organic matter in sustaining soil fertility. Nature 371:783-785. doi:10.1038/371783a0

Van Noordwjik M, Cerri C, Woomer P, Nugroho K, Bernoux M (1997) Soil carbon dynamics in the humid tropical forest zone. Geoderma 79:187-225. doi:10.1016/5006-7061(97)00042-6 
Walker MS, Desanker PV (2004) The impact of land use on soil carbon in Miombo woodlands of Malawi. For Ecol Manag 203:345-360. doi:10.1016/j.foreco.2004.08.004

Walkley A, Black IA (1934) An examination of the Degtjareff method for determining soil organic matter and a proposed modification of the chromic acid titration method. Soil Sci 37:29-38

Wei XR, Shao MG, Fu XL, Horton R (2010) Changes in soil organic carbon and total nitrogen after 28 years grassland afforestation: effects of tree species, slope position, and soil order. Plant Soil 331: 165-179. doi:10.1007/s11104-009-0122-9

Woodfine A (2009) Using sustainable land management practices to adapt to and mitigate climate change in sub-Saharan Africa: resource guide version 1.0. TerrAfrica. www.terrafrica.org

Yimer F, Ledin S, Abdelkadir A (2006) Soil organic carbon and total nitrogen stocks as affected by topographic aspect and vegetation in the Bale Mountains, Ethiopia. Geoderma 135:335-344. doi:10.1016 /j.geoderma.2006.01.005

Yimer F, Ledin S, Abdelkadir A (2007) Changes in soil organic carbon and total nitrogen contents in three adjacent land use types in the Bale Mountains, southeastern highlands of Ethiopia. For Ecol Manag 242:337-342. doi:10.1016/j.foreco.2007.01.087

Zenebe G (1999) Dessa'a protected area: an assessment of human impact, evolutionary pattern and options for sustainable management. Tigray Region Bureau of Agriculture and Natural Resources, Mekelle

Zhang ZS, Song XL, Lu XG, Xue ZS (2013) Ecological stoichiometry of carbon, nitrogen and phosphorus in estuarine wetland soils: influence of vegetation coverage, plant communities, geomorphology and seawalls. J Soils Sediments 13:1043-1051. doi:10.1007 /s11368-013-0693-3 